\title{
Antibacterial and antioxidant activities of ethanol extract of sukun (Artocarpus altilis.) leaves against Pseudomonas aeruginosa
}

\author{
Effendy De Lux Putra $^{{ }^{*}}$, Henni Cintya ${ }^{1}$, and Denny Satria ${ }^{1}$ \\ ${ }^{1}$ Department of Pharmaceutical Chemistry, Faculty of Pharmacy, Universitas Sumatera Utara, Jl. Tri \\ Dharma No.5, Medan, 20155, Sumatera Utara, Indonesia.
}

\begin{abstract}
Antioxidants are thought to help the body fight Reactive Oxygen Species (ROS). Antioxidants are defined as "any substance that significantly slows or inhibits oxidation when present in trace amounts relative to an oxidizable substrate." Antimicrobials generated from plants have been used to treat infectious diseases for millennia. Many investigations have been done on the antibacterial effects of herbal plant extracts., including roots, stems, leaves, and flowers. Artocarpus altilis is a versatile tree plant that is a rich source of calcium, phosphorus, carbohydrates, minerals, and vitamins. Various parts of breadfruit are used as food, cosmetic medicine, clothing, treating diarrhea, high blood pressure, and asthma. This study obtained about determine biological activities of Artocarpus altilis Leaves. The extract was prepared using water with the soxhletation method. The antibacterial activity was determined with minimun inhibitor concentration method with concentration $300-25 \mathrm{mg} / \mathrm{mL}$ can inhibit the growth of Pseudomonas aeruginosa, The MIC is the lowest concentration that may stop bacterial growth, and the number of bacteria is 10 colonies. $60.130 .54 \mathrm{ppm}$ antioxidant activity, fenol (224.67 $\mathrm{mg} \mathrm{GAE} / \mathrm{g})$ and flavonoids $(27.63 \mathrm{mg}$ $\mathrm{QE} / \mathrm{g}$ ). The results show that Artocarpus altilis leaf ethanol extract is antibacterial and antioxidant.
\end{abstract}

\section{Introduction}

Antioxidants are thought to be vital in the body's fight against Reactive Oxygen Species (ROS), Also known as superoxide anion (O2-), hydrogen peroxide (H2O2), and hydrogen radicals and critical role in signal transduction and pathogenesis, including cancer, aging, and other degenerative illnesses. Low doses of antioxidants significantly delay or prevent the oxidation of an oxidizable substrate. Plant antioxidants reduce reactive radicals to less reactive species. Fruits, vegetables, and tea contain antioxidants [1]. DPPH is a stable free radical compound was absorbance values ranged from 515-520 $\mathrm{nm}$ [2].

\footnotetext{
*Corresponding author: edeluxputra19@gmail.com
} 
For millennia, plants have been used to treat infectious diseases and are regarded a significant source of new antibiotics. Several studies have examined the antibacterial properties of herbal plant extracts (roots, stems, leaves, flowers) [3]. The dilution technique is used to measure the minimum inhibitory concentration (MIC) of antimicrobial drugs [4].

Artocarpus altilis is a versatile tree plant that is a rich source of calcium, phosphorus, carbohydrates, minerals, and vitamins. Breadfruit leaves are composed of various chemicals that have specific effects on the human body. The leaves of this plant are often used as traditional medicine by people who are believed to be able to cure certain diseases, so that researchers are interested in examining the content of breadfruit leaves and their benefits. From several studies conducted, breadfruit leaves are proven to be able to treat various diseases. Various parts of breadfruit are used as food, cosmetic medicine, clothing, treating diarrhea, high blood pressure, and asthma [5]. This plant has presented various pharmacological properties such as antimicrobial [5], antifungi [6], antioxidant [7], antiinflammatory [8], antidiabetic [9], anticancer [10], and antihyperlipidemic [11]. This plant contains terpenoid compounds, steroids, tannins, as it is known that tannins have good antioxidant and antibacterial activity [12].

\section{Material and methods}

\subsection{Material}

Fresh leaves of Artocarpus altilis were collected from the Faculty of Pharmacy, Universitas Sumatera Utara, Medan, Indonesia.

\subsection{Method}

\subsubsection{Preparation of extraction}

Artocarpus altilis leaves were pulverized at $45^{\circ} \mathrm{C}$. Simplicia powder $(30 \mathrm{~g})$ was put in a soxhlet extractor thimble. $600 \mathrm{~mL}$ ethanol into a conical flask. A heating mantle heated the solvent for 4 hours. In a water bath, the filtrate is concentrated to dryness using Whatman paper cones [13].

\subsubsection{Antioxidant activity}

$0.2 \mathrm{mM}$ DPPH was dissolved into methanol, and $1 \mathrm{ml}$ was taken to be added to the concentration variation. The samples were then incubated for 60 minutes, and the absorbance was measured at $516 \mathrm{~nm}$. Quercetin was used as a comparison [14,15].

\subsubsection{Total phenolic}

A total of $0.5 \mathrm{~mL}$ of $0.05 \%$ extract solution from and mixed with $0.75 \mathrm{~mL}$ of FolinCiocalteu reagent $10 \%$ and $2 \mathrm{~mL}$ of $\mathrm{Na}_{2} \mathrm{CO}_{3}(2 \% \mathrm{w} / \mathrm{v})$. Then the mixture was homogenized with a vortex for 15 seconds and heated at $45^{\circ} \mathrm{C}$ for 15 minutes. The absorbance of the sample was determined using a UV-Vis spectrophotometer. The total phenolic content was determined using a folin reagent. The absorbance was determined to be $775 \mathrm{~nm}$ when methanol solvent was used as a control [15]. 


\subsubsection{Total flavonoid}

The extract was dissolved in $10 \mathrm{~mL}$ of ethanol, to obtain a concentration of $1000 \mathrm{ppm}$. then the sample is pipetted and added $2 \% \mathrm{AlCl}_{3}$ solution and $1 \mathrm{~mL}$ of $120 \mathrm{mM}$ acetic acid were added. Samples were measured absorbance at $432 \mathrm{~nm}$ and used quercetin as a reference to create a calibration curve for flavonoids [16].

\subsubsection{Minimum inhibitory concentration}

Antibacterial activities of extracts were examined by minimum inhibitory concentration (MIC). A macro dilution approach was used in conjunction with Mueller Hinton Broth (MHB, Merck ${ }^{\circledR}$ ) as the test media to determine the minimum inhibitory concentration, with certain modifications. The Kirby-Bauer modified method, this method uses sterilized paper discs or discs. Paper discs with the same size with different concentrations are placed on agar media which will react with the bacteria being tested $[17,18]$.

\section{Results and discussion}

\subsection{Antioxidant activity, total phenol, and total flavonoid}

Antioxidant activity can capture free radicals and determine to decrease of absorption 516 $\mathrm{nm}$ caused by antioxidants reducing by $50 \%$ of DPPH. Phenol content in a sample can measure by total phenol. Plant phenolic compounds have redox characteristics that allow them to serve as antioxidants. Reduction occurs marked by a change in color from purple to yellow $[18,19]$. Reduced hydroperoxides and hydrogen peroxides and sequestered metal ions by complexation/chelation processes can reduce free radical production (Table 1).

Table 1. Antioxidant activity

\begin{tabular}{|c|c|c|c|}
\hline Extract & $\mathrm{IC}_{50}$ & Total phenolic & Total flavonoid \\
\hline Artocarpus altilis & $60.13 \pm 0.54 \mu \mathrm{g} / \mathrm{mL}$ & $\begin{array}{c}224.67 \pm 0.81 \mathrm{mg} \\
\text { GAE/g }\end{array}$ & $27.63 \pm 0.38 \mathrm{mg} \mathrm{QE} / \mathrm{g}$ \\
\hline
\end{tabular}

DPPH methods showed that the extract Artocarpus altilis with ethanol solvent had strong activity. This compound is one of the natural phenolic compounds, a derivative of hydroxybenzoic acid. The large variety of groups in the main phenolic framework causes the phenolic group to have many members. Gallic acid is reacted with Folin-Ciocalteu in an alkaline environment to produce a blackish green color that indicates positive or contains phenols [20]. Flavonoids occur in plants as a mixture of different flavonoids, and it is rare to find only a single flavonoid. Flavonoids in plants exist in various forms of molecular structures with several forms of glycoside combinations, and it is better to examine the hydrolyzed aglycones than in the form of glycosides with their complex and complex structure. Flavonoids can be efficacious as antioxidants, antibacterial, and antiinflammatory. UV-Vis Spectrophotometry was used to analyze flavonoids because they include conjugated aromatic [21]. 


\subsection{Antibacterial activity}

Based in Table 2, it can be seen that the concentration of 300 ppm up to a concentration of $25 \mathrm{ppm}$ can inhibit the growth of $P$. aeruginosa. P. aeruginosa is a normal flora of the intestine and human skin in small amounts and is the main pathogen in the Pseudomonas group. $P$. aeruginosa is widespread and is usually found in the humid environment of hospitals. These bacteria form saprophytic colonies in healthy humans, but cause disease in humans with inadequate body defenses. P. aeruginosa is the fourth most common nosocomial pathogen isolated from all hospital-acquired infections. MIC is the minimum concentration of antimicrobial substances that can inhibit bacterial growth after 24 hours of incubation and no known bacterial colonies grow by observing the number of bacterial colonies that grow [22].

Table 2. Result of antibacterial activity

\begin{tabular}{|c|c|c|c|c|c|c|}
\hline \multirow{3}{*}{ No } & \multirow{3}{*}{ Extract } & \multicolumn{5}{|c|}{ Inhibition zone diameter } \\
\cline { 3 - 7 } & & 300 & 200 & 100 & 50 & 25 \\
\hline \multirow{3}{*}{1} & \multirow{2}{*}{ Artocarpus altilis } & $\begin{array}{c}12.30 \pm \\
0,10\end{array}$ & $\begin{array}{c}11.97 \pm \\
0,05\end{array}$ & $\begin{array}{c}11.80 \pm \\
0,10\end{array}$ & $\begin{array}{c}11.10 \pm \\
0,09\end{array}$ & $\begin{array}{c}10.93 \pm \\
0,06\end{array}$ \\
\hline
\end{tabular}

Antibacterial activity depends on several factors, namely the concentration of the extract, the content of antibacterial compounds, the diffusion power of the extract, and the type of bacteria inhibited. The extract shows some of the high molecular weight of the component. Variations in extract concentration can be a factor inhibiting antibacterial activity by diffusion into bacterial media. When tested for phytochemical contents, the extracts revealed some variance in their presence or absence. The antibacterial activities of Artocarpus altilis leaves were verified by the presence of glycosides, alkaloids, and flavonoids. This study proposed that phytochemical components of plants that might either kill or hinder disease development be evaluated as possible antimicrobial medication options [23].

Flavonoids work by forming complexes with extracellular and soluble proteins and form complexes with cell walls, while the lipophilic nature of flavonoids disrupts microbial membranes. This situation will slowly prevent S.aureus from forming its defense system. After the defense system is disrupted, it will be easier to attack other parts of the cell in S. aureus so that its growth is inhibited and even killed.

Alkaloids can prevent the production of peptidoglycan cross-bridges in bacterial cells, preventing the formation of the cell wall layer. Because the bacterial cell wall is faulty, the osmotic pressure inside the cell is higher than outside. So bacteria die. Because triterpenoids are lipophilic, they cause damage to bacterial cell membranes. Antibacterial active chemicals can harm cell membranes by dissolving lipid components and increasing their permeability. Higher permeability allows antimicrobial chemicals into cells. These chemicals can lyse the bacterial cell membrane or coagulate the cytoplasm once inside [24].

The complexation of iron ions with tannins may explain the toxicity of tannins. Microorganisms growing under aerobic conditions require iron for various functions, including the reduction of DNA ribonucleotide precursors. This is due to the solid ironbinding capacity of tannins.

Antibacterial mechanism of saponins by damaging membranes the cytoplasm, which may be saponins, has a synergistic or additive effect with polyphenols in destroying the permeability of the bacterial cell itself. Saponins are amphipathic (containing hydrophilic and hydrophobic parts) which can dissolve membrane proteins. Hydrophobic saponins bind 
to the hydrophobic region of cell membrane proteins by shifting most of the bound lipid elements so that the bacterial cell becomes lysed [25].

\section{Conclusion}

Based on the research results that have been done, it can be concluded that the antibacterial activity of ethanol extract can inhibit the growth of $P$. aeruginosa bacteria in the concentration range of $25-300 \mu \mathrm{g} / \mathrm{mL}$. Breadfruit leaf ethanol extract has strong antioxidant activity using the DPPH method with IC50 values of $60.13 \pm 0.54 \mu \mathrm{g} / \mathrm{mL}$, total phenol $224.67 \pm 0.81 \mathrm{mg} \mathrm{GAE} / \mathrm{g}$ and total flavonoids $27.63 \pm 0.38 \mathrm{mg} \mathrm{QE} / \mathrm{g}$. The results water extract of Artocarpus altilis Leaves has antioxidant and antibacterial activity.

We gratefully thank to Research Center University of Sumatera Utara through Hibah Talenta "Hibah Penelitian Unggulan Universitas” Research Grant 2021.

\section{References}

1. A. Yadav, R. Kumari, A. Yadav, J.P. Mishra, S. Srivatva, Rsch in Envi \& If Scn, 9, $1328-1331$ (2016).

2. K.H. Marxen, S. Vanselow, R. Lippemeier, A. Hintz, U.P Ruser and Hansen, Sensors, 7, 2080-2095 (2007).

3. M.S, Bereksi, H. Hassaine, C. Bekhechi, D.E. Abdelouahid, Pharma Jour, 10, 507-512 (2008).

4. C. I. Owuama, Afr J Micro Rsch, 11, 977-980 (2017).

5. C. Pradhan, M. Monhanty, A. Rout, Front in Lf Scn, 2, (2012).

6. W.O. Cheong, S.C. Yik, S.K. Kong, C.O. Hean, W.S. Nam, A. Pac, J of Trop Biomed, 8, 313- 319 (2018).

7. S. Mukesh, Sikarwar, J.H. Boey, S. Kumutha, D.V. Bavani, K.Y. Ling, B. Kaveti, Free Rad \& Antiox, 4, 33-37 (2015).

8. D.H.S. Palupi, D.S. Retnoningrum, M.I. Iwo, A.A. Soemardji, Rasayan J. Chem, 13, $636-646$ (2020).

9. P.D.N. Lotulung, T. Mozef, C. Risdian, Indo. J. Chem, 14, 7 - 11 (2014).

10. E.T. Arungm, B.D. Wicaksono, Y.A. Handoko, I.W. Kusuma, D. Yulia, Trop J Pharm Res, 4, 317-324 (2009).

11. B.O. Ajiboyez, O.A. Ojo, I.Y Aganzi, G.S. Chikezie, O.A. Fadaka, K. Jayesimi, O. Olaoye, Int Fd Rsch J Journal, 24, 2133-2139 (2017).

12. V. Nayagam, K. Palanisamy, Thiraviadoss, J of Nan M, 2, 301 - 313 (2019).

13. O.R. Alara, N.H. Abdurahman, C.I. Ukaegbu, N.H. Azhari, Vernonia cinerea leaves as the source of phenolic compounds, antioxidants, and anti-diabetic activity using microwave-assisted extraction technique, Ind Crops and Prds, 122, pp. 533-544. (2018).

14. D. Satria, J. Silalahi, G. Haro, S. Ilyas, P.A.Z Hasibuan, Asian Pac J Cancer Prev, 18, 399-403 (2017).

15. Nazliniwaty, A.H. Olivia, P. Dewi, S. Denny, M. Mahatir, The Int Conf on Chem Sc Tech, 2342, 080010 (2021).

16. M. Rosidah, M.F. Yam, A. Sadikun, Pharm Bio, 46, 616-25 (2008). 
17. S. Jamuna, S. Pulsamy, K. Karthika, J App Pharm Sci, 2, 149-54 (2012).

18. H. Urip, D. Aminah, H. Triana, M. Mahatir, Nasri, S. Denny, The Int Con on Chem Sc Tech, 2342, 080011 (2021).

19. J. Boateng, and K.N. Diunase, Molecules, 20, (2015).

20. M.H. Kumar and Y.K., J Phyto, 9, 302-311 (2002).

21. A.B. Shoib, and A.M. Shahid, J Tai Univ Sc, 9, 449-454 (2015).

22. C.H. Chang, M.H. Yang, H.M. Wen, J.C Chern, J Fd Drug Anal, 10, 178-82 (2002).

23. J.B. Harborne, Metode Fitokimia; Penuntun Cara Modern Menganalisa Tumbuhan, (ITB, Bandung, 1987).

24. G.J. Tortora, B.R Funke, C.L. Case. Microbiology an Introduction, (Addison Wesley Longman Inc, San Fransisco 2010).

25. R. Ashok kumar, and M. Ramaswamy, Int J Curr Microbiol Appl Sci, 3, 395-406 (2014). 